\title{
ALTERNATIF BAGI PENGUATAN DEMOKRASI: PENGALAMAN MEKANISME ANGGARAN PARTISIPATIF (PARTICIPATORY BUDGETING) DI KOTA PORTO ALEGRE, BRAZIL
}

\author{
Zikril Hakim Badri \\ Universitas Indonesia, Depok. \\ Email : zikril.badri@gmail.com
}

\begin{abstract}
As a form of government in which the people who are sovereign and in power to determine their lives, democracy not only provides a breath of fresh openness and freedom but also promises a million hopes for a prosperous people's life. However, in line with the history of mankind, the government system that is predicted to be the best model of government from the worst, are also not free from problems, criticisms and crises that occur in it. The sovereignty of the people which has become the spirit of democracy has been eroded by the problem of the crisis of representation and direct involvement of the people in policy making. Democracy as a model of government reaps a crisis of public confidence which starts to regard this government system as an illusion of prosperity and justice. Interestingly, in the midst of the storm of problems that have plagued the democratic governance system in the present era, a breath of a new fresh air has emerged for the continuity of the sovereignty-based government system. In the city of Porto Alegre, Brazil, which is one of the main countries in the Latin American region, alternatives for strengthening participatory democracy have emerged through a model of governance based on Participatory Budgeting. "The implementation of this Participatory Budgeting has turned out to be able to restore the vital role of the people in policy making while at the same time improving the model of modern democratic governance which is increasingly hit by a crisis of trust and legitimacy from the people of today."
\end{abstract}

Keywords: Democracy, crisis of representation, alternative democracy, participatory budgeting

\section{PENDAHULUAN}

Pengertian tentang apakah yang disebut sebagai Demokrasi dapat dilacak sejak masa Yunani Kuno. Demokrasi berasal dari bahasa Yunani kuno yakni Kratos, yang diartikan sebagai kekuasaan atau pemerintahan dan Demos yang berarti orang banyak. Jadi demokrasi merupakan pemerintahan oleh banyak orang. Dalam kacamata pemikir-pemikir Yunani Kuno seperti Aristoteles, Demokrasi mengandung makna yang negatif karena mengandung kemungkinan bahwa pemerintahan akan dikendalikan oleh orang-orang yang miskin dan tidak terdidik. Demokrasi dengan demikian dapat menjadi musuh bagi kebebasan dan kebijaksanaan. Pemikir besar seperti Aristoteles sejak masa Yunani Kuno juga memperingatkan bahwa demokrasi bisa berkembang menjadi pemerintahan yang dibajak oleh segelintir orang yang tidak bertanggung jawab (mob rule) (Heywood, 2004).

Kekhawatiran Aristoteles ini sangat beralasan apabila kita menyimak sekilas sejarah perkembangan Demokrasi di dunia, terutama setelah lahirnya faham Liberalisme sebagai produk reformasi agama (Reformasi Gereja). Semangat kebebasan yang menjadi ruh daripada 
Liberalisme yang menentang absolutisme kekuasaan mendorong para filsuf-filsuf besar seperti John Locke, Jean Jasques Rousseau atau Montesquieu untuk merumuskan pemikiran yang berusaha mendesakralisasikan kekuasaan negara yang dominan. Hal ini terlihat dengan upaya membatasi kekuasaan dengan pembentukan lembaga perwakilan atau konsep pemisahan kekuasaan. Ide-ide filsuf Liberal ini kemudian dikembangkan termasuk dalam hal model pemerintahan atau kekuasaan politik yakni Demokrasi Perwakilan (Representative Democracy). Karena Demokrasi langsung dimana masyarakat terlibat secara penuh dalam pengambilan keputusan seperti masa Yunani Kuno dianggap tidak lagi relevan maka Demokrasi Perwakilan lewat pembentukan lembaga perwakilan (parlemen berikut wakilwakil rakyat didalamnya) dinilai sebagai jalan yang paling masuk akal dalam praktik politik kontemporer saat ini.

Meski demikian, salah seorang Presiden Amerika Serikat terkemuka yakni Abraham Lincoln pernah memperingatkan lebih dari satu abad yang lalu bahwa makna kebebasan yang menjadi fundamen utama Demokrasi berpotensi merusak nilai-nilai moralitas dari kebebasan itu sendiri. Menurut Lincoln, "Dunia tidak pernah memiliki definisi yang baik bagi kebebasan" (Nun, 2003). Kata-kata Lincoln inilah yang kiranya melekat pada model pemerintahan Demokrasi di masa kini. Demokrasi sudah berjalan keluar dari fitrahnya.Hal ini berawal ketika Demokrasi bertemu dengan sebentuk ideologi yang diametral dengan segala sesuatu yang kolektif yakni Liberalisme. Demokrasi sebagai demos atau kolektivitas politik tercabik oleh individualisme keras Liberalisme. Politik demokrasi bukan lagi pembangunan proyek-proyek kolektif (kesejahteraan umum), melainkan festival individualisme dan proseduralisme belaka (Adian, 2010). Demokrasi kini menyusut maknanya yakni sekadar pertarungan para elit politik yang mengatasnamakan rakyat dalam pemilihan umum yang dilakukan secara berkala. Pemilihan umum dan penempatan para elit politik atau wakil rakyat di lembaga perwakilan dianggap sudah merupakan prasyarat formal Demokrasi yang telah terpenuhi. Demokrasi Perwakilan juga semakin menjauh dari substansinya yang seharusnya melindungi kelompok masyarakat miskin dan termarjinalkan karena terbukti duduknya para elit politik di lembaga legislatif dan eksekutif tidak membawa perubahan signifikan bagi kesejahteraan rakyat. Tidaklah mengherankan apabila Demokrasi Perwakilan yang kini diterapkan di banyak negara-negara di dunia kini menghadapi dilema yang bersifat akut sebagaimana diungkap oleh Profesor Jose Nun dari Universitas Toronto, Kanada yakni 
apakah demokrasi sebagai pemerintahan oleh rakyat atau pemerintahan oleh para politisi ? (Nun, 2003).

Dilema Demokrasi Perwakilan inilah yang dapat kita lihat khususnya di negaranegara berkembang di kawasan Amerika Latin atau Asia. Di negara-negara di kawasan Amerika Latin seperti Bolivia misalnya, gelombang Transisi Demokrasi dan masuknya Bolivia ke dalam alam Demokrasi yang baru pada dekade 1980-an ternyata tidak membawa perubahan signifikan bagi perbaikan kesejahteraan masyarakat khususnya kelompok penduduk asli (indigenous). Meski mekanisme pemilihan umum sebagai aspek formal dari Demokrasi telah dilakukan namun ternyata sejak tahun 1985, konstelasi politik Bolivia dipegang oleh oligarki partai politik tradisional kelompok kulit putih keturunan Spanyol dan Mestizo yakni partai MNR (Movimiento Nacional Revolucionario), MIR (Movimiento Izquierda Revolucionario) dan ADN (Accion Democratica Nacional). Ketiga partai ini memiliki karakteristik yang sama yakni: kebijakan yang bersifat top-down, penuh dengan Klientelisme politik, korupsi pemerintahan yang merajelela dan ketidakmampuan mereka mengakomodir tuntutan dari kalangan masyarakat bawah (grass-root) terutama kelompok penduduk asli yang terbelenggu oleh jerat kemiskinan di negeri mereka sendiri (Irahola, 2005).

Hal yang sama terjadi di Indonesia pasca Transisi Demokrasi tahun 1998. Demokrasi Perwakilan belum mengalami pelembagaan kuat karena konteks politik di Indonesia masih didominasi oleh praktik politik uang dari para politisi serta ketidakmampuan partai politik menjalankan fungsi dan peranannya secara baik, sehingga kini muncul perlawanan terhadap dominasi partai politik yang korup lewat kemunculan calon-calon independen dalam konteks pemilihan kepala daerah (Pilkada) di berbagai daerah di Indonesia (Pratikno, 2007). Masih pada konteks yang sama, Indonesia telah menggelar serangkaian pemilihan umum secara langsung baik di tingkat nasional maupun lokal yang menjadi salah satu indikator pemerintahan berbasis demokrasi. Akan tetapi merujuk pada pengalaman Indonesia pasca transisi demokrasi tahun 1998, dapat dikatakan secara umum bahwa kualitas dan hakikat demokrasi yang bersandar pada kedaulatan rakyat belum terpenuhi. Pemilihan umum termasuk juga pemilihan kepala daerah justru hanya menjadi arena pertarungan para politisi untuk meraih jabatan-jabatan publik bahkan dengan praktik-praktik kotor seperti politik uang dan klientelisme politik. Desentralisasi yang juga menjadi bagian dari semangat membangun proses demokratisasi di Indonesia juga terjebak dalam serangkaian konflik antar elit politik di tingkat daerah dan juga menimbulkan gejala local bossism dimana para elit politik di daerah 
justru menjadi raja-raja kecil yang baru dalam konteks perpolitikan Indonesia di tingkat lokal (Henk Schulte Nordholt, 2007).

Pada tatataran lain, rakyat sebagai elemen penting dalam model pemerintahan Demokrasi semakin jauh dari keterlibatan langsung menentukan kebijakan dan pembangunan yang adil serta berpihak pada aspirasi dan kepentingan mereka. Demokrasi seolah makin tenggelam dalam gelapnya persoalan yang dihadapinya. Rakyat kian dilanda ketidakpercayaan bahwa Demokrasi sebagai model pemerintahan mampu membawa kesejahteraan dan keadilan. Sangat wajar dalam situasi demikian banyak orang bertanyatanya, masihkah Demokrasi dapat diharapkan sebagai model pemerintahan berbasis kedaulatan rakyat?

\section{KERANGKA ANALISIS}

Dalam tulisan ini penulis akan menggunakan perspektif teoritik demokrasi deliberatif yang digagas oleh Juergen Habermas. Penggunaan perspektif teori demokrasi deliberatif dari Habermas yang penulis gunakan tersebut menjadi rujukan alat analisis serta pengujian teoritis terhadap data empiris atau fenomena sosial nyata yang terjadi dalam penerapan mekanisme Participatory Budgeting di Porto Alegre, Brazil.

Pemikiran Habermas tentang konsep demokrasi deliberatif didasari oleh pemetaan yang dia lakukan terhadap 3 (tiga) konsep demokrasi, yaitu: (a) model liberal; (b)model republik; dan (c) model prosuderalis. Model terakhir inilah yang menjadi landasan pemikiran Habermas dalam mengembangkan konsep demokrasi deliberatif. Dalam pandangan Habermas, konsep deliberasi adalah prosedur sebuah keputusan dapat dihasilkan. Dengan kata lain, sebuah konsensus atau keputusan memiliki legitimasi jika sudah melalui proses pengujian atau diskursus, dimana semua isu dibahas bersama khususnya oleh pihak-pihak yang terlibat langsung dengan isu tersebut dalam posisi yang setara dan tanpa tekanan pihak lain (Farihah, Wahyuni) Konsep tersebut ingin meningkatkan intensitas partisipasi warga negara dalam proses pembentukan aspirasi dan opini agar kebijakan dan undang-undang yang dihasilkan oleh pihak yang memerintah semakin mendekati harapan pihak yang diperintah. Intensifikasi proses deliberasi lewat diskursus publik ini merupakan jalan untuk merealisasikan konsep demokrasi, Regeirung der Regierten (Pemerintahan oleh yang diperintah) (Farihah, Wahyuni)

Sementara itu, arena dimana "diskursus" tersebut dapat berlangsung, oleh Habermas disebut dengan publik sphere (ruang publik). Dalam pandangan Habermas, ruang publik 
adalah kehidupan sosial dimana opini publik dapat terbentuk. Habermas juga memaknai ruang publik sebagai hakekat kondisi-kondisi komunikasi yang dengannya sebuah formasi opini dan aspirasi diskursif sebuah publik yang terdiri dari warga negara dapat berlangsung (Farihah, Wahyuni) Dalam konteks masyarakat yang demokratis, akses untuk menyampaikan opini publik tersebut dijamin oleh negara, dimana opini publik lahir dari setiap pembicaraan para individu yang kemudian membentuk public body. Habermas menambahkan, bahwa warga berperilaku sebagai public body ketika mereka berbicara dalam cara yang tidak dilarang yaitu dengan jaimnan kebebasan berserikat dan berkumpul, serta kebebasan untuk mengekspresikan dan mempublikasikan pendapat mereka tentang hal-hal yang berkenaan dengan kepentingan umum. Inti dari pemikiran Habermas tersebut, semua produk hukum dan kebijakan yang dibuat oleh negara baik di ranah legislatif, eksekutif, dan yudikatif, harus melalui proses pengujian dan diskursus oleh civil society (Farihah, Wahyuni)

\section{METODE PENELITIAN}

Dalam tulisan ini penulis menggunakan metode penelitian kualitatif dan teknik pengumpulan data melalui studi kepustakaan atau literatur (literature studies). Terkait dengan penelitian kualitatif, Denzin dan Lincoln memberikan definisi sebagai berikut: Metode kualitatif adalah suatu aktivitas yang membawa peneliti untuk menelusuri dunia yang ada di sekelilingnya. Kegiatan tersebut berisikan seperangkat interpretasi, dan penerapan material yang membuat dunia terlihat lebih jelas. Aktifitas peneliti membawa dunia disekelilingnya kedalam berbagai wujudnya seperti: data di lapangan penelitian, interview atau wawancara, percakapan, foto-foto, rekaman percakapan ataupun pesan (memo). Pada level ini, penelitian kualitatif melibatkan interpretasi dan pendekatan alamiah terhadap dunia di sekelilingnya. Hal tersebut berarti, para peneliti kualitatif mempelajari suatu fenomena yang ada berdasarkan ketentuan alamiah, menempatkan perasaan dan kepekaan mereka, ataupun menginterpretasikan fenomena yang diberikan orang-orang disekitarnya kepada mereka (Lewis, Ritchie, 2003)

Teknik pengumpulan data yang penulis lakukan adalah studi kepustakaan atau literatur. Pengertian dari studi kepustakaan adalah serangkaian kegiatan yang berkenaan dengan metode pengumpulan data pustaka, membaca, mencatat serta mengolah bahan penelitian (Zed, 2004). Penulis menggunakan data dalam penelitian ini bersandarkan pada sumber buku, jurnal ilmiah ataupun website yang relevan dengan tema penelitian. Namun, 
keterbatasan dari penelitian ini adalah penulis tidak turun langsung mengumpulkan data melalui observasi atau pengamatan langsung di lapangan dan lebih mengandalkan data studi pustaka dalam hal pengumpulan data.

\section{PEMBAHASAN}

\section{Alternatif Baru Penguatan Demokrasi: Pelaksanaan Anggaran Partisipatif Di Porto} Alegre, Brazil

Meskipun Demokrasi sebagai model pemerintahan banyak negara-negara dunia di era modern mengalami rentetan persoalan dan krisis kepercayaan masyarakat, namun tidak serta merta bentuk pemerintahan ini menjadi kehilangan arah dan semakin ditinggalkan. Justru di tengah persoalan yang melilit model pemerintahan Demokrasi di berbagai belahan dunia saat ini, masyarakat, elemen-elemen gerakan sosial, civil society, intelektual penggiat demokrasi bahkan partai partai politik yang ada tidak pernah berhenti untuk terus mencari model alternatif pelaksanaan demokrasi yang tidak hanya bertumpu pada aspek-aspek kelembagaan (formal) saja tetapi menyentuh nilai Demokrasi yang sesungguhnya yakni keterlibatan rakyat dalam urusan publik dan pemerintahan. Salah satu kasus menarik mengenai munculnya alternatif bagi pelaksanaan Demokrasi ini terjadi di kota Porto Alegre, Brazil yang diinisiasi oleh Partai Buruh Brazil (Partido Dos Trabalhadores) bersama elemen-elemen gerakan sosial, aktivis, intelektual dan kelompok-kelompok civil society lainnya.

Mekanisme Anggaran Partisipatif atau kerap disebut Participatory Budgeting (PB) mulai efektif dilakukan semenjak tahun 1990 setelah koalisi partai kiri atau Aliansi Popular yang dipimpin Partai Buruh Brazil (Partido Dos Trabalhadores) memenangkan pemilihan umum tingkat lokal di Porto Alegre pada akhir tahun 1988. Kemenangan PT ini mengakhiri rentang panjang pemerintahan otoritarian diikuti dengan 3 tahun administrasi pemerintahan (1985-1989) Partai Buruh Demokratik (PDT/Partido Democratico Trabalhlista) yang dipimpin oleh walikota Alceu Collares (Triwibowo, 2009).

Sebagai catatan penting diawal penerapan Anggaran Partisipatif, Partai Buruh Brazil yang baru saja memenangkan pemilihan umum di tingkat lokal pada bulan Desember 1988 menghadapi berbagai problem warisan pemerintahan sebelumnya yang cukup pelik dan harus segera dipecahkan. Hiper-inflasi tengah melanda Brazil hingga mencapai angka $1783 \%$ dan di Porto Alegre mencapai angka 1744\%. Pada tingkat lokal, problem ini sangat nyata terlihat dengan permasalahan defisit keuangan dalam pemerintahan kota. Pemerintah lokal menaikan gaji para pegawainya hingga $110 \%$ pada paruh akhir bulan Desember 1988. Dengan kata 
lain, $98 \%$ penerimaan pemerintah kota dialokasikan untuk membayar gaji para pegawai negeri yang jumlahnya melonjak berkali-kali lipat pada masa pemerintahan sebelumnya (Bruce, 2004). Inefisiensi birokrasi ini di tingkat pemerintahan lokal termasuk Porto Alegre diperparah dengan sikap permisif atau lunak dari para birokrat pemerintahan lokal terhadap ulah para penunggak pajak, padahal penerimaan pajak sangatlah penting mendorong pembangunan kota dan program sosial termasuk pengurangan kemiskinan. Masyarakat kelas menengah ke atas yang berpenghasilan lebih justru dibebaskan dari beban pajak tinggi yang seharusnya mereka tanggung (Bruce, 2004). Dengan anggaran yang begitu kecil untuk pembangunan akibat inefisiensi birokrasi ini, maka pemerintah kota Porto Alegre menghadapi kesulitan keuangan dalam upaya mewujudkan program-program pembangunan dan pengurangan kemiskinan yang dijanjikan pada warga. Problem lainnya adalah belum munculnya kesadaran masyarakat terhadap konsep Anggaran Partisipatif yang ditawarkan oleh Partai Buruh. Muncul sikap skeptis dari masyarakat Porto Alegre sebagai akibat dari buruknya kinerja pemerintahan lokal sebelumnya dibawah Partai Buruh Demokratik (PDT).

Kesulitan anggaran dan skeptisime masyarakat terhadap penerapan Anggaran Partisipatif ini berangsur-angsur dapat diatasi memasuki tahun 1991 setelah pemerintah kota Porto Alegre dibawah pimpinan walikota Olivera Dutra memberlakukan serangkaian perubahan yang radikal dan inovasi penting dalam berbagai kebijakannya. Pertama-tama pemerintahan walikota Olivera Dutra melakukan reformasi perpajakan untuk membenahi sistem perpajakan yang kacau akibat para penunggak pajak. Pemerintah kota memaksa para penunggak pajak memenuhi kewajibannya dengan cara mempublikasikan nama-nama mereka secara terbuka, menyatakan penghentian pemberian amnesti dan pengampunan pajak, serta memberikan potongan pajak kepada warga kota yang membayar pajak lebih awal (Triwibowo, 2009). Selain itu, Dutra juga meluncurkan lima belas peraturan perpajakan yang baru untuk menggali sumber-sumber perpajakan baru yang legal serta mereformasi skema pajak lokal yang ada. Salah satunya lewat pajak properti perkotaan atau IPTU (Property Tax For Urban Land and Homeownership) dan indeksasi terhadap beberapa jenis pajak dan pungutan lokal seperti pengumpulan sampah guna mengendalikan inflasi. Pengawasan pembayaran pajak dan pembayaran tarif yang efisien juga diberlakukan oleh pemerintah kota. Hasil dari reformasi perpajakan ini ternyata berhasil membawa perubahan yang signifikan bagi peningkatan pendapatan kota Porto Alegre, yakni dari kisaran 5,8 \% pada tahun 1990, kemudian bertambah menjadi 13,8\% pada tahun 1992 dan pada tahun 1998 berada di kisaran antara 17 hingga 18\% (Santos, 1998). 
Setelah mampu memperbaiki pendapatan kota Porto Alegre yang begitu krusial dalam pembiayaan pembangunan dan program-program sosial bagi masyarakat, Partai Buruh (Partido Dos Trabalhaldores) mulai dapat dengan leluasa melaksanakan program Anggaran Partisipatif dimana pemerintah kota melibatkan secara langsung masyarakat Porto Alegre yang tergabung dalam wadah forum-forum warga untuk ikut serta merumuskan kebijakan di tingkat lokal. Pemerintah kota Porto Alegre memulai proses Anggaran Partisipatif dengan membagi wilayah kota menjadi 16 bagian distrik untuk memudahkan pengakomodasian diskusi warga secara efektif. Secara umum, pelembagaan partisipasi warga ini membentuk sebuah piramida partisipasi yang mengkombinasikan demokrasi melalui partisipasi langsung di tingkat mikro dengan sistem perwakilan ditataran piramida yang lebih tinggi (Marion Gret, 2005).

Piramida ini disusun oleh forum-forum diskusi publik di tingkat komunitas (micro level pyramid) yang diorganisasikan langsung oleh warga dan asosiasi-asosiasi warga. Forum ini membahas kebutuhan dan prioritas dari kebutuhan investasi warga, merumuskan usulan investasi yang akan dibawa kedalam tataran piramida partisipasi yang lebih tinggi serta memilih juru bicara untuk menyampaikan usulan tersebut. Hirarki berikutnya adalah forum publik di tingkat distrik (distric level pyramid). Forum ini membahas usulan-usulan investasi dari proses di tingkat mikro, menentukan prioritas investasi dari distrik tersebut, memilih utusan bagi Forum de Delegados yang akan membantu kerja dewan anggaran dan proses Anggaran Partisipatif, serta konselor yang akan duduk dalam dewan Anggaran Partisipatif. Pada tataran ini juga berlangsung pertemuan-pertemuan tematik (Plenarias Tematica) yang memfasilitasi diskusi-diskusi tematik khusus seperti transportasi publik, budaya, pertumbuhan ekonomi dan perpajakan, pendidikan, pembangunan sosial dan perkotaan serta kesehatan dan kesejahteraan sosial yang melibatkan birokrasi pemerintahan kota maupun asosiasi-asosiasi sektoral untuk menentukan prioritas investasi sektoral di tingkat kota. Forum ini juga berhak memilih utusan mereka untuk duduk dalam Dewan Anggaran Partisipatif.

Hirarki tertinggi dalam piramida partisipasi adalah di tingkat kota dimana Dewan Anggaran Partisipatif mewakili warga dalam menegoisasikan proposal investasi yang dihasilkan proses Anggaran Partisipatif dengan pemerintah kota. Para konselor yang duduk di dewan ini mewakili warga di enam belas distrik kota Porto Alegre (dua konselor di tiap distrik dan dua cadangan pengganti), peserta forum tematik (satu konselor untuk setiap tema dan satu cadangan pengganti untuk tiap tema), utusan serikat pekerja kota/SIMPA, dan 
utusan persatuan asosiasi warga kota Porto Alegre/UAMPA (masing-masing dua konselor dan dua cadangan pengganti), serta perwakilan dari pemerintah kota yaitu GAPLAN (Gabinete de Planejamento/Badan perencanaan) dan CRC (Coordenacao de Relacoes com e Comunicade/Komisi Hubungan Masyarakat) masing-masing dua konselor dan dua cadangan pengganti. Dewan Anggaran Partisipatif ini bertugas selama satu tahun untuk memonitor proses Anggaran Partisipatif, mengevaluasi dan menyetujui proposal investasi yang dihasilkan oleh Anggaran Partisipatif untuk diajukan ke pemerintahan kota, serta mengevaluasi realisasi implementasi anggaran dan proposal investasi pada tahun sebelumnya.

Selain melibatkan warga Porto Alegre dalam proses Anggaran Partisipatif, pemerintah kota Porto Alegre juga melakukan reformasi birokrasi. Reformasi ini dilakukan dengan merombak birokrasi lama dan menciptakan lembaga-lembaga baru yang lebih sesuai dengan karakteristik proses Anggaran Partisipatif. Pada masa pemerintahan walikota Olivera dibentuk GAPLAN (Gabinete de Planejamento/Badan perencanaan) yang langsung bertanggung jawab terhadap walikota untuk mengkordinasikan aspek-aspek teknik proses penyusunan anggaran, seperti penilaian kelayakan teknis terhadap proposal-proposal investasi serta pengintegrasian proposal-proposal tersebut dalam anggaran kota, menghubungkan proses AP dengan lembaga-lembaga sektoral di tingkat kota. Dutra juga memberikan fungsi baru bagi CRC (Coordenacao de Relacoes com e Comunicade/Komisi Hubungan Masyarakat) untuk menghubungkan birokrasi pemerintah kota dengan asosiasiasosiasi warga dan organisasi berbasis komunitas untuk memfasilitasi berlangsungnya forumforum publik dalam mekanisme Anggaran Partispatif. Reformasi ini diikuti pula dengan pembentukan CROP (Coordenador Regional do OP) dan CTs (Coordenador Tematico) serta CARs (Centros Administrativos Regionalis). CROPs dan CTs terdiri dari staf pemerintah kota yang diberi tugas untuk memberi masukan teknis dan dukungan politik dalam proses AP di enam belas distrik dan enam forum diskusi tematik. CARs disisi lain, merupakan organ pemerintahan kota yang diberi tugas untuk memberikan dukungan administrasi dasar bagi proses AP serta penyediaan pelayanan dasar bagi warga kota (Triwibowo, 2009).

Langkah lain yang tak kalah pentingnya dilakukan oleh pemerintah kota Porto Alegre dibawah Partai Buruh (Partido Dos Trabahaldores) adalah meningkatkan efisiensi alokasi investasi dan sumberdaya yang terbatas. Mekanisme AP berupaya meningkatkan efisiensi alokasi anggaran bagi investasi dengan menetapkan seperangkat kriteria untuk mengidentifikasikan kebutuhan yang menjadi prioritas utama warga kota serta mendistribusikan investasi tersebut kepada distrik yang paling membutuhkan. Dalam proses 
AP, setiap distrik harus memilih empat prioritas investasi sektoral dari tiga belas pilihan yang ada, yaitu air bersih, perumahan, infrastruktur jalan, pendidikan, bantuan sosial, kesehatan, transportasi, area rekreasi, fasilitas olah raga, penerangan jalan, pengembangan ekonomi, budaya, dan peningkatan kualitas hidup. Masing-masing prioritas di setiap distrik kemudian diberi bobot berdasarkan urutannya (nilai 4 untuk prioritas pertama hingga 1 untuk prioritas keempat) sehingga akhirnya didapatkan urutan prioritas investasi sektoral di tingkat kota berdasarkan akumulasi pembobotan prioritas sektoral distrik tersebut. Masukan ini kemudian diolah dalam bentuk matriks dengan bantuan GAPLAN untuk menentukan alokasi anggaran bagi tiap prioritas sektoral sesuai dengan alokasi anggaran investasi pemerintah kota (Triwibowo, 2009).

\section{Hasil Pencapaian Dari Pelaksanaan Anggaran Partisipatif di Porto Alegre}

Pelaksanaan Anggaran Partisipatif dalam pemerintahan kota Porto Alegre sudah berjalan selama lebih dari dua dekade semenjak Partai Buruh (Partido Dos Trabahaldores) mengagas kebijakan ini di penghujung tahun 1988. Semenjak era walikota Olivera Dutra, pelaksanaan Anggaran Partisipatif ini terus dipertahankan oleh pemerintahan kota Porto Alegre dibawah pimpinan walikota lainnya seperti Tarso Genso dan Raul Pont. Lalu sejauh mana hasil yang dicapai dalam penerapan Anggaran Partisipatif ini ? Ternyata dari penelitian para ilmuwan membuktikan bahwa penerapan Anggaran Partisipatif ini telah membawa dampak yang positif bagi kesejahteraan warga kota khususnya kelompok miskin, peningkatan pelayanan publik yang signifikan serta menguatnya demokrasi yang partisipatif lewat keterlibatan warga dan kelompok civil society di Porto Alegre.

Selama dekade 1990-an, administrasi pemerintahan kota berhasil meraih pendapatan pemerintahan kota yang besar dan pada saat yang bersamaan mengurangi beban hutang pemerintahan kota. Hasilnya, pemerintah kota Porto Alegre dapat meningkatkan pendanaan investasi untuk pembangunan dan program-program sosial yang penting bagi masyarakat. Hampir dari setengah anggaran investasi diprioritaskan untuk memenuhi tuntutan komunitas warga Porto Alegre dan setengahnya lagi untuk pendanaan administrasi dan hal-hal teknis yang diprioritaskan oleh aparatur pemerintahan kota, dan hal ini pun tetap didiskusikan dengan komunitas, forum warga dan juga Dewan Anggaran Partisipatif (COP). Diperkirakan sekitar 35\% anggaran pendapatan kota dialokasikan ke kawasan-kawasan kecil di kota Porto Alegre (Triwibowo, 2009). 
Dalam penelitiannya, ilmuwan politik, A. Marquetti mencatat bahwa ada pergeseran alokasi investasi publik dalam anggaran tahunan pemerintah kota. Rencana investasi publik ini secara sistematis dibicarakan dalam forum-forum dan pertemuan warga kota dan kelompok civil society. Sejak awal 1990an, implementasi dari program Anggaran Partisipatif ini terus meningkat sampai mendekati angka $90 \%$ oleh karenanya dapat dikatakan bahwa rencana pembangunan kota merupakan hasil yang valid dari proses Anggaran Partisipatif yang melibatkan warga kota. Marquetti juga menyoroti kecenderungan bahwa alokasi pendanaan anggaran kota diprioritaskan untuk distrik-distrik yang dihuni populasi penduduk miskin di kota Porto Alegre. Sebagai tambahan, investasi publik ini diutamakan untuk konsumsi kolektif atau kebutuhuhan dasar masyarakat seperti air, mandi cuci kakus (MCK), pengerasan jalan, penerangan listrik, dan sistem drainase. Area kedua yang menjadi prioritas adalah fasilitas pendidikan, perumahan dan sertifikat tanah, serta pelayanan kesehatan. Berbagai kemajuan penting ditunjukan dengan meningkatnya pengerasan jalan sebagai tuntutan utama dari banyak organisasi akar rumput (grass root) di Porto Alegre serta di bidang pendidikan (Koonings, 2004).

Di bidang pelayanan publik keberhasilan penerapan Anggaran Partisipatif ini ditunjukan dengan meningkatnya akses warga terhadap air bersih yang mencapai angka 99\% dan ketersediaan saluran pembuangan air (sewage system) atau Mandi Cuci Kakus (MCK) yang layak mencapai angka $83 \%$. Sebagai perbandingan, diawal masa pemerintahan Partai Buruh pada tahun 1988, ketersediaan saluran pembuangan yang layak ini hanya berkisar di angka 50\%. Semenjak mekanisme Anggaran Partisipatif diterapkan di Porto Alegre yang diusung oleh Partai Buruh bekerjasama dengan masyarakat dan civil society, lebih dari 250 kilometer jalanan dan jembatan dibangun dan diperkeras (pengaspalan dan pengeringan jalan) khususnya di wilayah-wilayah miskin kota Porto Alegre. Pengeluaran publik untuk perumahan meningkat tajam dalam kurun waktu 1989 dan 2000. Dalam rentang waktu yang sama, jumlah anak yang duduk di bangku sekolah meningkat tajam (dari rata-rata sebesar 20 menjadi 90) dan rata-rata anak yang putus sekolah menurun drastis dari sekitar 30\% menjadi hanya $10 \%$ saja. Sebanyak 114 komunitas warga kota yang baru mulai menerima pendanaan dari pemerintah lokal dimana pada masa-masa sebelumnya hal ini tidak pernah terjadi. Tempat penitipan anak bagi ibu-ibu pekerja meningkat tiga kali lipat pada periode yang sama. Dan dalam hal transportasi publik, angkutan bus kota di Porto Alegre merupakan yang pertama di Brazil dalam menerapkan akses bagi pengguna kursi roda (wheelchair). Akibat kesuksesan dari penerapan Anggaran Partisipatif di kota Porto Alegre, Anggaran Partisipatif 
kini diterapkan di beberapa kota di Brazil dan diakui oleh Perserikatan Bangsa Bangsa (PBB) sebagai contoh teladan dari tata pemerintahan kota yang baik (Bruce, 2004).

Peningkatan kualitas demokrasi yang partisipatoris juga terjadi di Porto Alegre semenjak diterapkannya mekanisme Anggaran Partisipatif. Jumlah warga yang terlibat dalam proses di dalam piramida partisipasi tidak hanya secara kuantitas terus meningkat tapi juga mampu memfasilitasi terjadinya pembalikan hirarki sosial (reversal of social hirarchies) dengan keterlibatan yang kuat dari kaum miskin, perempuan dan populasi usia muda. Dalam penelitian yang dilakukan oleh L. Fedozzi, Z. Navarro serta Andreas Novy dan Berhard Leubolt terungkap bahwa keterlibatan masyarakat dalam pertemuan distrik maupun tematik meningkat dari 976 orang pada tahun 1990, menjadi 10.375 orang pada tahun 1993 dan melonjak lagi menjadi 28.907 orang pada tahun 2002 (Andreas Novy, 2005) (lihat dalam grafik 1). Berikut dibawah ini grafik lengkap partisipasi warga dalam mekanisme Anggaran Partisipatif di Porto Alegre dari tahun 1989 hingga 2003.

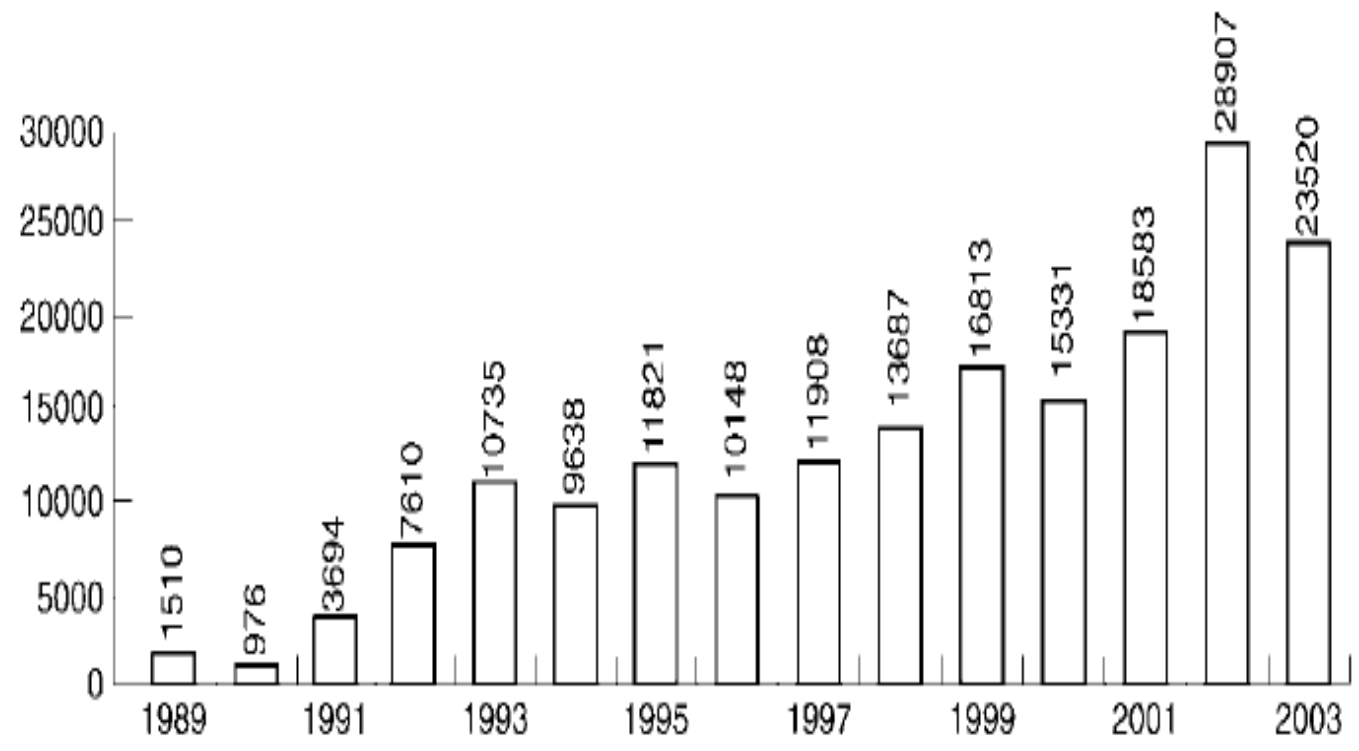

Grafik 1. Jumlah Partisipasi Warga Porto Alegre Dalam Mekanisme Anggaran Partisipatif Sumber: Andreas Novy, Bernhard Leubolt, 2005

Studi empiris menunjukan bahwa kelompok-kelompok yang selama ini kerap diabaikan dalam proses pengambilan kebijakan khususnya perempuan dan masyarakat miskin telah merasakan dampak positif dari penerapan Anggaran Partisipatif ini. Partisipasi perempuan dalam mekanisme Anggaran Partisipatif meningkat dari 46,7 \% pada tahun 1993 menjadi 
56,4\% pada tahun 2002 lebih tinggi dari populasi penduduk perempuan di Porto Alegre yang mencapai 53, 3\%. Kelompok-kelompok lain yang secara tradisi termarjinalkan seperti komunitas masyarakat kulit hitam dan kelompok masyarakat miskin juga mendapat keterwakilan yang baik dalam mekanisme Anggaran Partisipatif ini (Andreas Novy, 2005).

Survei yang dilakukan CIDADE juga membuktikan bahwa jumlah warga berusia 16 hingga 25 tahun yang terlibat dalam mekanisme Anggaran Partisipatif terus meningkat. Sedangkan partisipan yang berusia kurang dari 35 tahun juga menyusun lebih dari $30 \%$ total partisipan AP pada periode yang sama. Proporsi ini jauh melampaui presentase mereka yang berusia lebih dari 50 tahun (22-25,9\%). Di sisi lainnya, keterlibatan warga dengan tingkat pendapatan yang lebih rendah ikut meningkat pula. Pada tahun 1998, survei mencatat bahwa partisipan terbesar dalam AP adalah warga dengan tingkat pendapatan yang lebih rendah dari dua kali pendapatan minimum. Jumlah ini terus meningkat dari 30,9\% pada tahun 1998 hingga mencapai 39,4\% pada rahun 2002. Forum-forum publik di distrik yang lebih miskin juga dihadiri oleh lebih banyak partisipan (Triwibowo, 2009).

Mekanisme Anggaran Partisipatif Porto Alegre dinilai berhasil membangun sebuah sistem kelembagaan alternatif yang memungkinkan warga untuk ikut menentukan prioritas dan alokasi anggaran pelayanan publik pemerintah kota. Melalui skema Anggaran Partisipatif, Porto Alegre berhasil mencangkokkan prinsip-prinsip partisipasi yang sebelumnya berkembang di tataran masyarakat sipil ke dalam arena politik lokal serta mentransformasikan sistim demokrasi dari "democracy of voters" menjadi "democracy of citizens" (Triwibowo, 2009) Hampir dua dekade sejak inovasi AP dikembangkan pada tahun 1988, skema tersebut berhasil mengubah perilaku korup birokrasi kota menjadi transparan dan akuntabel, mereduksi praktik klientelisme dalam sistem politik lokal, serta mendorong redistribusi sumberdaya kepada kelompok-kelompok miskin dan marjinal. Skema AP secara bersamaan juga berhasil meningkatkan kinerja pelayanan publik, khususnya dalam pelayanan sanitasi dasar, perumahan dan infrastruktur jalan. (Triwibowo, 2009) Sebagai konsekuensi atas kesuksesan dari mekanisme AP di Porto Alegre ini, Partai Buruh Brazil (Partido Dos Trabahaldores atau PT) berhasil meraih reputasi sebagai partai yang mampu menciptakan pemerintahan yang baik (good governance) serta mendorong partai-partai lokal di Brazil untuk menerapkan mekanisme Anggaran Partisipatif yang saat ini tersebar hingga ke 400 kota di Brazil termasuk kota metropolitan Belo Horizonte dan Sao Paolo (Patrick, 2011). 


\section{KESIMPULAN}

Eksperimen demokrasi partisipatoris yang dilaksanakan lewat mekanisme Anggaran Partisipatif di Porto Alegre, Brazil menunjukan kepada kita betapa pentingnya melembagakan demokrasi secara partisipatoris yang mampu menyentuh ruang-ruang publik secara nyata dalam praktik pemerintahan. Demokrasi tidaklah cukup bersandarkan pada mekanisme-mekanisme prosedural seperti pemilihan umum dan terbentuknya lembaga perwakilan rakyat karena terbukti tanpa komitmen yang kuat terhadap pemenuhan kesejahteraan rakyat dan upaya-upaya untuk mengakomodir aspirasi dan kepentingan rakyat, demokrasi dapat dibajak oleh segelintir elit politisi dengan label sebagai "wakil rakyat" yang duduk dalam pemerintahan. Demokrasi dengan demikian telah keluar dari makna sesungguhnya yang sejatinya merupakan alat perjuangan bersama untuk melawan ketidakadilan dan absolutisme kekuasaan. Dalam kondisi dilema demokrasi perwakilan yang hingga saat ini masih terjadi, pelaksanaan demokrasi partisipatoris di Porto Alegre lewat penerapan Anggaran Partisipatif tidak saja berhasil mengangkat kembali relevansi dasar dari demokrasi yakni siapa mewakili siapa ? tapi juga memberikan alternatif solusi bagi pelembagaan demokrasi yang kuat berakar dari tataran akar rumput (grass-root) atau masyarakat terbawah dalam struktur sosial. Penerapan Anggaran Partisipatif (Participatory Budgeting) di Porto Alegre juga menjadi contoh nyata konsep teoritis demokrasi deliberatif yang penulis gunakan dalam penelitian ini. Masyarakat atau warga negara dalam mekanisme demokrasi bukanlah subjek pasif melainkan aktif dalam proses pengambilan kebijakan secara terbuka di ruang publik (public sphere).

Sebagai penutup penulis memandang bahwa negeri kita, Indonesia kiranya bisa memetik pelajaran berharga dari pengalaman mekanisme Anggaran Partisipatif (Participatory Budgeting) di kota Porto Alegre, Brazil. Refleksi pembelajaran dari kasus pelaksanaan Anggaran Partisipatif (Participatory Budgeting) ini menjadi sangat penting bagi Indonesia, mengingat dua dekade sejak Indonesia dilanda transisi demokrasi pada 1998, belum banyak perubahan signifikan yang dapat dirasakan oleh masyarakat khususnya dalam konteks kesejahteraan dan keadilan sosial. Kondisi tersebut sangat ironis mengingat praktik-praktik Demokrasi secara formal dan kelembagaan sudah dijalankan melalui pemilihan umum di tingkat nasional maupun lokal namun ternyata secara esensial tidak membawa lembaran kehidupan baru yang lebih menggembirakan bagi rakyat secara keseluruhan. Di titik itulah tugas kita bersama yang tetap mengusung cita-cita keadilan dan kesejahteraan untuk terus 
memperbaiki model pemerintahan Demokrasi yang telah kita pilih menggantikan model kekuasaan absolut dan otoritarian Orde Baru yang telah bertahan selama 32 tahun lamanya. Demokrasi bukan sekadar pemerintahan rakyat tanpa makna dan hanya prosedural saja sebaliknya Demokrasi yang hakiki merupakan bentuk pemerintahan di tangan rakyat marjinal dan tertindas yang berdaulat menentukan arah nasibnya sendiri menuju pintu gerbang kesejahteraan dan keadilan.

\section{DAFTAR PUSTAKA}

Adian, D. G. (2010). Demokrasi Sebstansial : Risalah Kebangkrutan Liberalisme . Depok : Koekoesan.

Andreas Novy, B. L. (2005). Participatory Budgeting in Porto Alegre : Social Innovation and The Dialectical of State and Civil Society. Journal of Urban Studies, Volume 42, Nomor 11, 2023-2036.

Bruce, I. (2004). The Porto Alegre Alternative : Direct Democracy in Action . London: Pluto Press.

Farihah, L, Sri Wahyuni, D. "Demokrasi Deliberatif Dalam Proses Pembentukan UndangUndang di Indonesia: Penerapan dan Tantangan ke Depan". Makalah Ilmiah Lembaga Kajian dan Adovaksi untuk Independesi Peradilan, tidak diterbitkan.

Henk Schulte Nordholt, G. V. (2007). Politik Lokal di Indonesia. Jakarta: Yayasan Obor Indonesia.

Heywood, A. (2004). Political Theory : An Introduction, Third Edition. New York : Palgrave McMilan.

Irahola, D. L. (2005). Popular Participation, Decentralization, and Local Power Relation in Bolivia . Gottingen : Cuvillier Verlag Press.

Koonings, K. (2004). Strengthening Citizenship in Brazil's Democracy : Local Participatory Governance in Porto Alegre. Bulletin of Latin America Research, Volume 23, Nomor 1, 79-99.

Marion Gret, Y. S. (2005). The Porto Alegre Experiment : Learning Lessons for Better Democracy. London: Zed Books.

Lewis, J, Ritchie, J. (2003). Qualitative Research Practice: A Guide For Social Sciences Students and Researcher

London: Zed Books

Nun, J. (2003). Democracy; Government of The Pepople or Government of The Politician. Oxford: Rowman \& Littlefield.

Patrick, H. (2011, September 1-4). Participation, Democracy, and Development : Some Comparative Lesson from Brazil, India, and South Africa. Participatory Governance : Reshaping Democracy, Economic Security, and Social Justice, p. 12.

Pratikno. (2007). Calon Independen, Kualitas Pilkada, dan Pelembagaan Parpol. Jurnal Ilmu Sosial dan Ilmu Politik, Volume 10, Nomor 3, 415-438.

Santos, B. d. (1998). Participatory Bedgeting in Porto Alegre : Toward a Redistributive Democracy . Journal Politics \& Society, Volume 26, Nomor 4, 461-510.

Triwibowo, D. (2009). Melembagakan Partisipasi dala Desentralisasi : Pengalaman Anggaran Partisipatif di Kota Porto Alegre, dan Kota-Kota di Brazil. In N. I. Darmawan Triwibowo, Meretas Arah Kebijakan Sosial Baru di Indonesia, Lebih dari Sekedar Pengurungan Kemiskinan (p. 288). Jakarta: LP3ES.

Zed, M. (2004). Metode Penelitian Kepustakaan, Jakarta:Yayasan Obor Indonesia. 